\title{
ИНВЕСТИЦИИ В РАЗВИТИЕ ЧЕЛОВЕКА КАК ФАКТОР ЭКОНОМИЧЕСКОГО РОСТА
}

\author{
Афанасьева Анна Юрьевна \\ Донской государственный технический \\ университет \\ Filippovaanna88@yandex.ru
}

\section{INVESTMENTS IN HUMAN DEVELOPMENT AS FACTOR OF ECONOMIC GROWTH}

\section{A. Afanasyeva}

Summary. The relevance of scientific research is due to the fact that the efficiency of the use and development of human capital is the main priority. According to the UN report of 2000 , in which the criteria and ways of development of the millennium were formulated. It is human capital that contributes to an increase in the quality of life of the population, as well as an increase in the efficiency of the national economy as a whole.

Keywords: human capital, human choice human resources, human potential, individual value.
B ажнейшим фактором развития государства является человек. У человека есть право получить тот уровень жизни, который он считает достойным. При этом социально-экономическое развитие государства является показателем развития человеческого капитала, но внешнеэкономические показатели (ВВП и ВНП) не должны воздействовать на развитие общества, иначе этот путь заметно ухудшит состояние страны.

Переворот в экономической науке совершил Армартье Сена, представив концепцию оценки внутренних потребностей и уровня жизни по желанию людей, а не из расчета на душу населения. Доход - это средство, расширяющее возможности выбора и обеспечивающее жизнедеятельность человека от элементарных потребностей в области здравоохранения, образования, экономической и общественной деятельности до более широкого спектра потребностей (свободы, вариантов выбора цели и образа жизни, которые больше подходят для конкретной личности). Ученый полагал, что человеческое развитие «представляет собой как процесс расширения человеческого выбора, так и достигнутый уровень благосостояния людей».

Безграничный выбор определяет безграничный спектр проблем, который меняется в соответствии с историческими циклами.
Как полагал Аристотель, «...богатство, очевидно, не является тем, к чему мы стремимся, потому что оно просто получено и служит чему-то другому». Философ обращается к вопросу возможности реализации жизненных ресурсов, получения и распределения благ. Если обратиться к «Докладу о человеческом развитии» за 2001 год, можно выявить, что термин «человеческое развитие» определяется созданием среды, в которой люди могут развить свой потенциал и вести продуктивную и творческую деятельность в зависимости от своих желаний и потребностей. Базисными потребностями являются долгая и здоровая жизнь, информированность, наличие средств к существованию, участие в жизни общества.

Важный вектор развития качества жизни создает образование, которое расширяет мировоззрение и создает новое качество жизни. Профессор д.э.н. Н.Д. Колесов вводит категорию «человеческий потенциал», которая шире категории «человеческий капитал». Все человеческое развитие рассматривается как двухсторонний процесс: как развитие способностей, а также как реализация способностей.

Отличительная черта человеческого капитала неотделимость от личности своего носителя. Человеческий капитал имеет множество измерений и может 
приобретаться различными путями - в семье, в учебных заведениях, на рабочих местах и т.д. Основными видами вложений в человека считаются, согласно К. Макконнелл и С. Брю, «... образование, производственная подготовка, охрана здоровья, миграция, поиск информации на рынке труда, рождение и воспитание детей». Образование и производственная подготовка увеличивают объем капитала одной личности. Охрана здоровья и здоровый образ жизни увеличивают срок службы каждого человеческого капитала. Миграция и поиск информации создает рынок труда. Рождение и воспитание детей создает функцию реализации капитала - семью и множество других социальных аспектов, которые мы обсудим ниже.

Согласно Энгелю (1883 г.), формирование мужчин как взрослых индивидов завершается к 26 годам, а женщин к 20 годам. Он полагал, что для родителей, принадлежащих к разным социальным слоям, стоимость рождения ребенка будет неодинаковой: если для представителей низшего класса она оценивалась им в 100 марок, то для представителей среднего класса - в 200 марок, а для представителей высшего класса - в 300 марок. Существует одно допущение, из которого он исходил, которое заключалось в том, что по мере увеличения возраста ребенка стоимость его содержания увеличивается ежегодно в арифметической прогрессии с шагом $10 \%$ от издержек рождения.

\section{Формула Энгеля:}

$\mathrm{ci}(\mathrm{x})=\mathrm{cO} \mathrm{i}+\mathrm{cO} \mathrm{i}^{*}\left[\mathrm{x}+0,5^{*} \mathrm{k}^{*} \mathrm{x}(\mathrm{x}+1)\right] ;$

где $\mathrm{ci}(\mathrm{x})$ - кумулятивные издержки содержания ребенка до возраста $\mathrm{x}$ лет родителями, принадлежащими к i-му социальному классу; с0і - издержки его рождения; с0i*k - шаг прогрессии при k, равном 0,1.

Выделим два основных направления государственного финансирования отраслей образования и здравоохранения, поскольку Россия не компенсирует расходы на трудовую миграцию, как, например Израиль. В размерах нашей страны это представляется невыполнимым, но, с другой стороны, встает вопрос о равных конституционных правах граждан на труд, например, если сравнить Москву и отдаленные регионы страны.

Капитал можно только «арендовать», приняв работника на работу. И тем самым капитал, вложенный в обучение сотрудника и его здоровье, «амортизируется» в данной единице - личности. При увольнении сотрудника работодатель безвозвратно теряет человеческий капитал конкретной личности. Джонс Чирипанхура в 2010 отметил, что, согласно действующей методологии СНС, человеческий капитал не включается в число капитальных активов на том основании, что он имеет ряд особенностей: 1) относится к категории «качество» и нематериален; 2) принадлежит только индивиду (знания и навыки индивида невозможно передать от одного человека к другому (cannot transferred to others), и они не совместимы с категориями бухгалтерского учета предприятия); 3) не поддается измерению и изменяется во времени; 4) несовместим с конвенциями и институтами, регулирующими стандартные трансакции, которые получают отражение в финансовой отчетности.

Можно выделить три основных подхода к решению этой проблемы: 1) «индикаторный», основанный на различных натуральных характеристиках человеческого капитала; 2) стоимостный, основанный на учете издержек, связанных с его формированием; 3) стоимостный, основанный на учете получаемых от него доходов. Р. Фарр в своих трудах связал капитал индивида и его работу: «.капитал, воплощенный в индивидах, можно оценивать исходя из суммарного дохода, который им предстоит получить на рынке в течение последующей жизни». В известной книге Л. Дублина и Э. Лотки «Денежная ценность человека» 1930 года ценность индивида на момент рождения VO определялась в ней по формуле:

$$
\infty \mathrm{V} 0=\Sigma \mathrm{PO}
$$

$\Sigma P 0=x(y x E x-c x) /(1+i) x$

где $x=0$

где і - норма процента;

Р0, $\mathrm{x}$ - вероятность дожития до возраста $\mathrm{x}$ лет при рождении;

yx - годовой доход индивида в возрасте х лет;

Ех - вероятность быть занятым в возрасте х лет;

сx - издержки проживания (living expenses) в период от х до $\mathrm{x}+1$ лет.

Ценность индивида изменяется от издержек на транспорт, медицинское обслуживание, так как вероятность дожить и выжить часто зависит от уровня и доступности здравоохранения, а уровень заработанной платы от образования.

Теодор Шульц и Гэри Беккер сформулировали экономический подход к человеческому поведению. Основой подхода стало положение, что любая человеческая деятельность представляет собой психологическую энергию, которая необходима для того или иного вида деятельности. По мнению ученых, экономический взгляд на психику представляет её в качестве системы, управляемой энергией инстинктов, а различия между сознательной (эго) и бессознательной (ид) областями понимаются через призму различий в уровне и форме распределения энергии между этими областями. Экономический подход состоит в том, что распределение 
энергии представляется в виде конечного продукта деятельности, объекта, источника и уровня напряжения. Исследования Шульца и Беккера были сосредоточены на изучении «человеческого капитала» как фактора экономического, социального развития цивилизации, включающего образованную часть трудовых ресурсов, знаний и умений, обеспечивающего эффективное и рациональное функционирование человека как производительного фактора развития.

Концептуальный подход к человеческому развитию, разработанный группой экспертов Программы развития ООН (ПРООН) и впервые изложенный во всемирном Докладе о человеческом развитии за 1990 год, впоследствии ставшем ежегодным, рассматривает развитие человеческого капитала как самоцель и критерий общественного прогресса.

В 2000 году были сформированы цели и задачи тысячелетия. Неотъемлемая часть задач и целей, поставленных в Декларации тысячелетия,- создание концепции человеческого развития и обеспечение человеческой безопасности. Политику развития поддерживает и Российская Федерация.

Каждый год президент РФ В.В.Путин в обращении к федеральному собранию делает основной акцент на социальном развитии общества. Лидер страны широко обозначил вектор развития нового тысячелетия, направленный на улучшение благосостояния семей с детьми для увеличения численности населения. С 2020 года за первого ребенка мать будет получать 450 тыс. руб., что составляет около 40,8 прожиточных минимумов, за второго ребенка - 13,2 прожиточных минимумов, за третьего ребенка - 40,8 прожиточных минимумов. Также государство обеспечивает отпуск по беременности и родам с оплатой оплаты труда в 1,5 больше обычного на 140 календарных дней и оплату отпуска по уходу за ребенком до 1,5 лет. Также существует доплата семьям, в которых доход не превышает 1,5 прожиточных минимума на человека, пока родитель находится в декретном отпуске, т.е. до достижения ребенком 3 лет, и с 3 до 7 дет - в размере половины прожиточного минимума.

Государство помогает обеспечить граждан жильем и возвращает ранее оплаченный налог за покупку недвижимости до 260 тыс. руб. В случае, если на покупку жилья был взят кредит, государство возмещает 13\% от выплаченной суммы до 3 миллионов рублей.

Адресная помощь, связанная с возвратом части ранее уплаченного налога на доходы физического лица, существует и в других социальных отраслях: образовании, здравоохранении и т.д.
На здравоохранение в 2020 году было выделено 0,990 трлн. руб.- примерно 1/20 бюджета страны. В 1975 году было выделено 11,6 млрд. руб - примерно 1/19 бюджета страны. В 2020 году бюджет на здравоохранение доказал свою социальную значимость. Весь мир захватила пандемия коронавируса, и выделенных средств явно оказалось недостаточно, поэтому правительство в федеральный бюджет дополнительно выделили 300 миллиардов рублей.

Увеличилась социальная нагрузка на здравоохранение в связи с увеличением пенсионного возраста: число пенсионеров по старости и инвалидности составляет 38847 человек (за 2019 год) [проверить эту цифру]. Также выросло количество людей предпенсионного возраста, вместе эти категории граждан составляют более 1/3 части населения, чем и оправданны данные расходы.

Расходы на образование составили 0,886 трлн. руб. в 2020 году, или 1/25 от годового бюджета страны. В годы расцвета нашей страны на науку и просвещение выделялась 1/6 всего бюджета. Однако и сегодня образование остается зоной ответственности для правительства России.

После распада СССР, взяв на себя огромный внешний долг, Россия выплатила его, и сейчас первоочередной задачей является развитие человеческого капитала. Обратимся к интервью Д. Буша Старшего, который считает Россию процветающей страной, которая обеспечила социальную помощь для бывших республик СССР и оказалась способна реализовывать свой потенциал в развитии собственного народа.

Сравнив данные показатели, следует сказать, что Россия занимает достойное место в числе стран с социально развитой системой обслуживания населения, увеличивая инвестиции государства и увеличивая численность населения, и вносит вклад в инвестирование в человеческий капитал страны. Меры, предпринятые в сфере здравоохранения в кризисный год пандемии, доказали, что политика социальной защиты здоровья является действенной и система здравоохранения способна обеспечить безопасность жизни и здоровья граждан страны.

Основными составляющими стоимостного значения человеческого капитала является здравоохранение, образование, мобильность, рождение и воспитание детей, чем и оправданы меры поддержки социальной политики государства. По вопросу цивилизационного развития страны следует заключить следующее: государство достигло точки наивысшего социального развития в 1975 году. Однако и спустя 45 лет социальные приоритеты государства остались прежними и инвестиции 
в человеческий капитал не потеряли значимости для страны. Россию можно назвать социальным государством с социально-развитой системой обслуживания населения. При увеличении инвестиций увеличивается численность граждан, следовательно, и человеческий капитал страны.

\section{ЛИТЕРАТУРА}

1. Человеческое развитие: новое измерение социально-экономического прогресса: учебное пособие / В. П. Колесова. Москва: Права человека. 2008.636 с.

2. Капелюшников Р.И.: Сколько стоит человеческий капитал России? Москва: Изд. дом Высшей школы экономики. 2012. 76 с.

3. Корицкий А.В., Введение в теорию человеческого капитала: к 667 учебное пособие/ Новосибирск: СибУПК, 2000. 112 с.

4. Макконнелл К., Брю С. Экономикс. Принципы и проблемы и политика. 14-е изд., дораб. и испр. Москва: Инфра-М, 2003. 972 с.

5. Нестерова А.В. / Молодой учёный / Международный научный журнал № 39 (173) / 2017. [Электронный ресypc]URL: https://moluch.ru/archive/173/45771/ (дата обращения: 02.04.2018).

6. Петрова Д.Д, Маштак А.А // Государственные инвестиции в образование России / Статья в периодическом журнале ФГБоу ВО «Российский экономический университет им. Г. В. Плеханова». [Электронный ресурc]. URL: https://interactive-plus.ru/e-articles/182/Action182-13960.pdf (дата 0бращения: 02.04.2018).

7. Статистика // Федеральной Налоговой службы РФ. [Электронный ресурc]. URL: https://www.nalog.ru/ (дата обращения: 19.02.2020).

8. Федеральный портал // Развитие человеческого потенциала в России. [Электронный ресурc]. URL: http://www.protown.ru/information/hide/7452.html (дата обращения: 23.03.2018).

9. Статистические данные // Федеральная служба государственной статистики. [Электронный ресуpc]. URL: http://www.gks.ru (дата 0бращения: 23.03.2018).

10. Послание Президента России к Федеральному собранию // [Электронный ресурс] URL: http://www.kremlin.ru/events/president/news/62582 (дата обращения: 19.02.2020).

11. Консультант плюс // Федеральный закон N459. [Электронный ресурс]. URL: http://www.consultant.ru/document/cons_doc_LAW_312362/78600ea41960f82 849d7e67e13af14863f325f19/(дата обращения: 19.02.2020).

12. Государственный бюджет СССР и Союзных республик 1971-1975 г.г. // [Электронный ресурс] URL: http://istmat.info/files/uploads/47313/81_ gosudarstvennyy_byudzhet_sssr_i_soyuznyh_respublik_1971-1975.pdf (дата обращения: 19.02.2020).

13. ФИНКАН // Бюджет России на 2020 год в цифрах. [Электронный ресурс]. URL: http://fincan.ru/articles/112_byudzhet-rossii-na-2020-god-v-cifrah/ (дата 0бращения: 19.02.2020).

14. Конт // Джордж Буш: «Развал Советского Союза — есть мое самое Главное Поражение». [Электронный ресурc]. URL: https://cont.ws/@teem75/211681 (дата обращения: 19.02.2020).

15. In Russia. [Электронный ресурс] URL: http://www.protown.ru/information/hide/7452.html (дата обращения: 19.02.2020).

(c) Афанасьева Анна Юрьевна ( Filippovaanna88@yandex.ru).

Журнал «Современная наука: актуальные проблемы теории и практики» 